\title{
Belgeo
}

Revue belge de géographie

$1 \mid 2017$

Miscellaneous

\section{Can Putnam's theory explain high levels of social trust?}

La théorie de Putnam's peut-elle expliquer l'ampleur de la confiance sociale?

\section{Maria Arup Hovmand and Gert Tinggaard Svendsen}

\section{(2) OpenEdition}

\section{Journals}

\section{Electronic version}

URL: http://journals.openedition.org/belgeo/20518

DOI: $10.4000 /$ belgeo.20518

ISSN: 2294-9135

\section{Publisher:}

National Committee of Geography of Belgium, Société Royale Belge de Géographie

\section{Electronic reference}

Maria Arup Hovmand and Gert Tinggaard Svendsen, « Can Putnam's theory explain high levels of social trust? », Belgeo [Online], 1 | 2017, Online since 31 March 2017, connection on 22 April 2019. URL : http://journals.openedition.org/belgeo/20518; DOI : 10.4000/belgeo.20518

This text was automatically generated on 22 April 2019

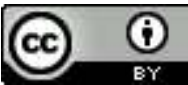

Belgeo est mis à disposition selon les termes de la licence Creative Commons Attribution 4.0 International. 


\section{Can Putnam's theory explain high levels of social trust?}

La théorie de Putnam's peut-elle expliquer l'ampleur de la confiance sociale?

Maria Arup Hovmand and Gert Tinggaard Svendsen

\section{Introduction}

1 When observing social trust across nations, we observe a huge variation within total averages. In general, Scandinavia ranks at the top whereas South American and African countries hit the bottom (World Values Survey, 2017; Svendsen and Svendsen, 2015). We do, however, also observe regional variation allowing us to undertake an even more focused study of the origins of trust at the local level. In fact, in 2016 we found that the level of social trust in the rural peripheral area of Ringkøbing Skjern Municipality (RSM) represents the highest score registered to our knowledge, namely a score of $91 \%$. These data from a representative sample of local RSM's citizens were collected in cooperation with RSM's Department of Analysis during February and March 2016. The results show that more than nine out of ten citizens in RSM believe that in general other people are trustworthy (Citizen Panel Survey on Social Capital, 2016; Epinion, 2015).

What is going on then in this fairy-tale country of Hans Christian Andersen where a policeman will stop the traffic to let a duck family pass the street? Fukuyama (2011), for example, speaks about "Getting to Denmark" and how to transform countries such as Afghanistan, Iraq or Somalia using Denmark as a role model. Another example is Bernie Sanders who - during the recent US election campaign - spoke about Denmark as the land of opportunities (Skov, 2015). The roots of social trust may, perhaps suprisingsly, lie in peripheral, rural areas like the RSM. If so, this new and overlooked resource may be used as a new brand to attract newcomers thus helping overcoming the spatial distance to the relatively more attractive urban areas.

In fact, social trust is arguably an important precondition for a stable and peaceful society where people tend to cooperate rather than to defect (Ostrom and Ahn, 2009). Social 
control in relation to social trust norms creates predictable behavior and less free-riding (Ostrom, 1990). Social trust as a relation between people has traditionally largely been overlooked by economists as a "missing link" when trying to explain the wealth of a nation (Gundlach and Svendsen, 2017). Thus, lower transaction costs in the economy and at the local level arguably lead to higher economic growth (Bjørnskov, 2009). Overall, the presence of social trust helps overcoming the collective action problem as suggested by Olson (1965). The big puzzle in the literature, however, is how social trust is accumulated over time (Svendsen and Svendsen, 2016a).

Our main research aim in this article is to investigate whether one possible explanation could be rooted in the "voluntariness matters" camp. As argued by Putnam (2000), there is a positive effect of voluntariness on trust in the United States. Putnam's original analysis of the historical roots in North and South Italy highlights the importance of voluntary meeting places (Putnam, 1993). Consequently, the main research question is:

\section{Can Putnam's theory on voluntarism explain the high level of social trust in Ringkøbing-Skjern Municipality (RSM), Denmark?}

5 Such understanding has many interesting perspectives for e.g. attracting tourists or new citizens to the country or a rural area. When citizens tend to cooperate and self-regulate behavior, security levels may increase as well which is a crucial factor when tourists decide upon their travel destination (Jensen and Svendsen, 2016). Furthermore, in this way, social trust can be embedded in the service package that may be offered locally (Tiebout, 1956).

6 In the following, we will study the roots of social trust empirically by undertaking a focused case study at the local level in RSM. This approach is useful for geography because peripheral areas within a country may have other and overlooked competition parameters when competing with other areas for attracting newcomers to their location. First, we present Putnam's approach leading to the deduction of a hypothesis on voluntariness. Next follows the analysis and finally, a conclusion is given.

\section{Theory}

\section{Putnam's theory and critics}

7 Putnam investigates civic engagement in the United States focusing on membership of and activities in voluntary organizations (Putnam, 2000, p. 49). Putnam furthermore finds, geographically speaking, that those who participate in local voluntary work also carry more trust (Putnam, 2000, p. 137). In this way, a positive correlation between social networks, such as voluntary organizations, and trust is established. These results indicate that geography may be relevant for the size of social trust in peripheral rural areas.

The norm that mainly increases trust among local citizens is generalized reciprocity. It means that local individuals mutually expect that actions undertaken are returned at some future point in time. Such norm and socialization reduces the risk of free-riding and lowers transaction costs (Putnam, 1993, pp. 171-172). Thus, Putnam's theory can be placed within Ostrom's second-generation rational models concerning social interaction as it focuses explicitly on social networks in voluntary organizations with face-to-face 
interaction where norms have to be respected due to social control - not only direct economic incentives matter (Ostrom 1990; Poulsen 2009; Poulsen and Svendsen 2005). The Putnam theory has been discussed widely in the literature and we refer to five main criticisms.

First, Putnam has been criticized for focusing only on the positive aspects of trust. Social trust may not be the only solution to most problems in society. Portes and Landolt (1996) have argued that if social trust can explain all positive things in society, then it explains nothing. A negative aspect could be when ethnic groups become outsiders in a high-trust society. In this situation, qualifications no longer decide who will get the best jobs and less cooperation will have a negative impact on the overall economy. Even though there may be negative aspects too, one could, however, argue that the positive aspects still prevail.

Second, a potential problem concerning causality is a selection bias. Those who choose to undertake voluntary work may carry a high level of social trust beforehand as compared to the general level in the population. This means that social trust is not created while being voluntary but rather that people with high trust are more likely to join in compared to people with low trust who are more sceptical towards initiating social interaction with strangers (van Ingen and Bekkers, 2015). Selection bias and the direction of causality has not yet been settled in the literature (Ostrom and Ahn, 2009). Therefore, it is still interesting to test the Putnam claim.

11 Third, rather than an institutional cause following a learning process in voluntary organizations, social trust could be inherited and caused by the specific cultural context. Eric Uslaner, for example, argues that trust is stable over time and does not change fundamentally over a life time in spite of possible events. In contrast, trust is a given thing inherited from our parents and grandparents (Uslaner, 2002, pp. 76-77). Still, even if trust is evolutionary and a basic personality trait, it does not mean that the individual level of social trust cannot be changed over time due to socialization in networks.

12 Fourth, voluntary organizations may have changed somewhat from traditional face-toface relations to less direct physical interaction. Earlier on citizens tended to meet physically in the voluntary organizations but nowadays this participation may be partly replaced by regular economic support without people actually showing up. If so, civic engagement can no longer be just as important a cause to social trust as earlier on (Freitag, 2003, pp. 945-946). A discussion here is that even if physical face-to-face relations no longer are as frequent as earlier on in voluntary organizations, present social interaction may continue to have significant explanatory power.

Fifth, a historical critique has been launched. Putnam (1993) argues that the different levels of civic engagement in North and South Italy are due to early historical events, especially the $11^{\text {th }}$ century Norman kingdom of Sicily. According to Morlino (1995), this is a strong simplification of historical events and their consequences. Futhermore, the borders between the North and South have not been stable over time. Present borders are different from the historical borders questioning the continuity and path dependency that Putnam suggests (Morlino, 1995). There are, however, many ways to analyse historical events within different scientific disciplines and therefore it may be difficult to agree on which method is the optimal one to use.

Overall, the critique of Putnam's theory does not necessarily mean that the Putnam claim is wrong. Also, the critique reflects differences between the methods in different 
scientific disciplines. Bearing this in mind, it is still relevant to test the Putnam theory arguing that, in general, people are less inclined to cheat in a social network where they meet other people face-to-face. Social networks increase the level of communication and exchange of information about the trustworthiness of other participants. Social rewards and punishments ensure in this way predictable behavior and therefore make it easier to cooperate. As voluntary organizations typically have free access, the positive experiences and trust generated here among many different individuals will then spread out in society as social trust (Putnam, 2000, pp. 173-74). In summary, we can deduct the following Putnam hypothesis:

\section{Voluntary work has a positive effect on the level of social trust}

\section{Analysis}

\section{The case of Ringkøbing-Skjern Municipality}

Ringkøbing-Skjern Municipality (RSM) has 57,000 inhabitants and is situated in the peripheral western part of the Danish peninsula Jutland. Thus, RSM is situated in rural Denmark where it has been hard to attract newcomers (Svendsen and Svendsen, 2001, 2016b), see map in Figure 1.

Figure 1. Map showing the municipality of Ringkjøbing-Skjern in Denmark.

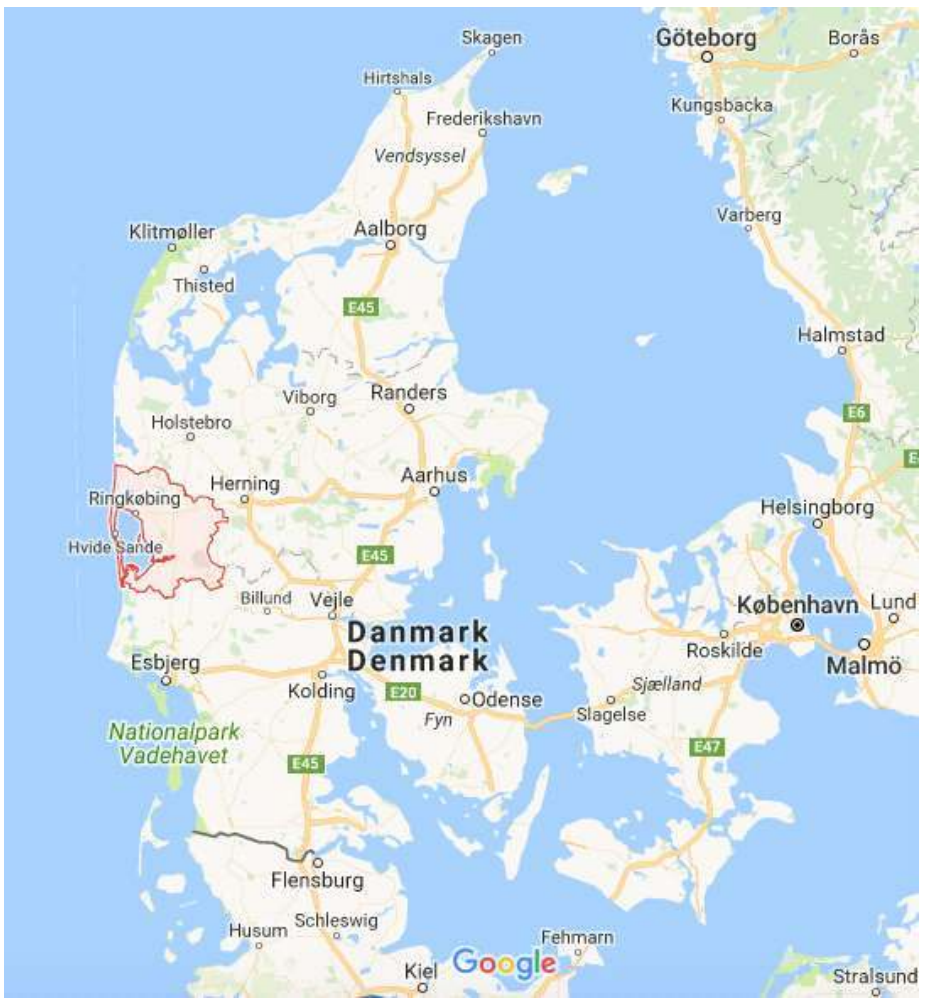

SOURCE: GOOgLE (2017) 

citizen associations included (Ringkøbing Skjern Municipality, 2017a, 2017b). Associations without taxable income are not obliged to register officially, which is why the exact number of voluntary associations is difficult to pin down (SKAT, 2017). Of the 580 associations, 150 or around $25 \%$ are sports associations. The association density in the municipality was 98, i.e. an average of 98 inhabitants per association in the year 2015. Later data collected from the Citizen Panel Survey on Social Capital 2016 shows how many of the municipality's citizens are doing voluntary work within an association. RSM has organized four main initiatives during the years to support the present and future voluntary work at the local level.

First of all, RSM has put voluntary work on their political agenda, which is specifically made clear in their "Fritidslivspolitik" ("Leisure official program"). The programs's vision is that "the active life within culture and leisure strengthens the cohesion and shared identity in our municipality", which is to be achieved through the following three objectives:

- We make sure that everyone has the opportunity to participate in active communities by engaging in shared interests, challenging one self and each other, and learning by new experiences in the community.

- We create the setting for the development of the activities within culture and leisure with respect for what already exists.

- We utilize nature's rich resources in the development of culture and leisure facilities.

This focus on voluntary associations is seen in the first objective where the RSM, in cooperation with other parties, wants to create a setting in which citizens, associations and institutions can develop new initiatives (Ringkøbing Skjern Municipality, 2017a). With this program, the municipality is supporting the activities within the voluntary associations in cooperation with its citizens at the local level.

Second, the RSM introduced in 2010 a "Volunteer Award" which is a prize of DKK 5,000 given to a person, association or organization in acknowledgement of a special effort in promoting social, voluntary work. The municipality's reasons for appointing a candidate to the prize has been to award a contribution for encouraging cooperation across the community of voluntarism, for drawing attention to a hitherto unknown problem, or for doing an unprecedented effort for many years (Ringkøbing Skjern Municipality, 2010). Other Danish municipalities are also giving a "Volunteer Award", for example Hillerød and Aalborg municipalities (Hillerød Municipality, 2017; Aalborg Municipality, 2017).

Third, a Volunteer Council has been set up and consists of 11 members. One member is appointed from within the Social and Health Committee, one is appointed by the Volunteer Centre, and the remaining 9 are appointed among the voluntary associations at the annual dialogue meeting (Volunteer Council, 2011). The Volunteer Council's object is “...in cooperation with Ringkøbing Skjern Municipality to develop and adjust the volunteer policy for the voluntary social work by functioning as a connecting link and dialogue forum between the actors in the voluntary social field and Ringkøbing Skjern Municipality, and to advise the municipality in the voluntary social field."

21 The Volunteer Council is to achieve this through its tasks regarding development of the voluntary working field, taking part in the distribution of funds to voluntary associations, promotion of cooperation between voluntary actors and is being used for municipal hearings regarding proposed policies, initiatives or arrangements that influence on the 
voluntary field in the municipality (ibid., $\S \S 2$ and 3). Thus, the Volunteer Council is furthering democracy in the municipal activities by increasing citizen involvement, in this case volunteers, in hearings and dialogue meetings but also in the development of policies in relevant fields.

Finally, the "Voluntarism and Dedicated Soul Academy" (VDSA) was created as a selfgoverning institution in 2015. The VDSA's object is to develop and strengthen the voluntary field in the local rural area. It offers courses, education and lectures for volunteers and facilitates cooperation across municipalities, regions, associations and organizations. It connects fiery souls and volunteers in order for them to profit from each other's abilities and work to increase the visibility of voluntary work. RSM is a part of the VDSA since they have one permanent member in the Council of Representatives (the highest authority within the VDSA), and one other permanent member of the Academy Board. Furthermore, RSM supports the VDSA with an operational grant of DKK 300,000 over a three-year period running from the academy's creation in 2015 (The Voluntarism and Dedicated Soul Academy, 2016). By the active participation with representatives in both the Council of Representatives and the Board of the VDSA, and taking care of half of the academy's economic foundation, RSM is a part of the work of spreading knowledge, developing and increasing the cooperation with local voluntary associations.

\section{The Putnam hypothesis}

According to the Putnam hypothesis, we expected that voluntary work would have a positive effect on the level of social trust. In order to evaluate the effect of voluntary work in the peripheral rural area of RSM, the relevant questions and national data for Denmark in the European Values Study from 2015 will be included (European Values Study, 2015).

First, we will go through the frequency distribution of the citizens doing voluntary work in RSM and Denmark and next we will analyse and discuss the logistic estimates and marginal effects. The estimates from the logistic regression, log-odds, are not very intuitive to make a substantial interpretation of (Sønderskov, 2015, p. 256). Thus, we will only interpret the direction (positive or negative) of the log-odds and the P-value. Second, the logistic regression is used to calculate the marginal effects of voluntary work (independent variable) on social trust (dependent variable) in order to determine the size of the voluntary work's effect.

The marginal effects are calculated for an interesting observation on the voluntary work variable: those who actually do voluntary work in rural RSM compared to the national level in Denmark. The marginal effect is interpreted as the predicted probability of a high level of trust for the category "doing voluntary work" in the variable voluntary work (ibid ., p. 260). The independent variable, voluntary work, encompasses only those who do voluntary work in an association they have stated to be a member of. This means that those who do voluntary work without being a member of a specific association are not included in this variable. Table 1 shows the frequency distribution (in percentage) of the respondents doing voluntary work in a voluntary association. 
Table 1. Voluntary work in RSM and Denmark.

\begin{tabular}{|l|l|l|}
\hline & Ringkøbing-Skjern (RSM) & Denmark \\
\hline Voluntary work & $57 \%(601)$ & $38 \%(550)$ \\
\hline$N$ & 1048 & 1459 \\
\hline
\end{tabular}

SOURCE: THE CITIZEN PANEL SURVEY ON SOCIAL CAPITAL 2016 AND THE EUROPEAN VALUES STUDY 2015.

The frequency distribution in Table 1 shows that there is a marked difference between RSM and Denmark in general when it comes to volunteering in a voluntary association. While more than half of the respondents are volunteering in RSM, this same number is only $38 \%$ for all Danes. This is a difference of almost 20 percentage points.

The results support the Putnam hypothesis since there is also a higher level of social trust in RSM (91\%) compared to Denmark (76\%), see Svendsen and Svendsen (2015). This is interesting and calls for a more thorough analysis in order to determine a statistical relationship and thereby prove or disprove our hypothesis.

In the following section, the log-odds and marginal effects, also known as predicted probabilities, will be analysed and the data for RSM and Denmark will be compared. Table 2 gives an overview of the results of the logistic regression where we have controlled for education level, age and gender. These standard controls have been included in the analysis in order to minimize the probability of spuriosity in the relationship. As the table demonstrates, the log-odds for voluntary work are positive and statistically significant at the 0.001-level for both RSM and Denmark. Both cases thus demonstrate a positive and statistically significant effect of doing voluntary work on the citizens' social trust.

Table 2. The effect of voluntary work on social trust.

\begin{tabular}{|l|l|l|}
\hline & Ringkøbing-Skjern & Denmark \\
\hline Voluntary work & $0,35^{* *}$ & $0,46^{* * *}$ \\
\hline Educational level & $0,59^{* * *}$ & $0,49^{* * *}$ \\
\hline Age & 0,005 & $-0,008^{*}$ \\
\hline Gender & $0,68^{* *}$ & $-0,03$ \\
\hline$N$ & 1048 & 1459 \\
\hline
\end{tabular}

${ }^{*} p<0,05, * * p<0,01, * * * p<0,001$

SOURCE: THE CITITZEN PANEL SURVEY ON SOCIAL TRUST 2016 AND THE EUROPEAN VALUES STUDY 2015

What cannot be derived from these log-odds in Table 2, however, is the size of the effect.

Thus, in order to determine the effect size of voluntary work on social trust, the marginal effects have been calculated from the logistic regression. The marginal effects of 
voluntary work are interpreted as the probability of a high level of social trust when an individual is doing voluntary work. Table 3 illustrates the marginal effects of doing voluntary work in RSM and Denmark respectively.

Table 3. Voluntary work and marginal effects.

\begin{tabular}{|l|l|l|}
\hline & Ringkøbing-Skjern & Denmark \\
\hline Voluntary work & $0,93^{* * *}$ & $0,82^{* * *}$ \\
\hline$N$ & 1048 & 1459 \\
\hline
\end{tabular}

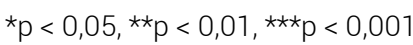

SOURCE: THE CITIZEN PANEL SURVEY ON SOCIAL CAPITAL 2016 AND THE EUROPEAN VALUES STUDY 2015

31 As shown in Table 3, the marginal effect for doing voluntary work in RSM is 0.93 and for Denmark 0.82. Both estimates are statistically significant at the 0.001-level. This means that the citizens of RSM who work voluntarily in a voluntary association with a 93\% probability have a high level of social trust. Compared to Denmark in general, the marginal effect is 11 percentage points lower, meaning that there is an 11 percentage point lower probability of a high level of social trust among volunteering Danes in general. Not alone does voluntary work prove as a very good probability predictor for high social trust levels among volunteers in RSM, this number is also much higher than for Danish citizens in general.

32 Applying Putnam's theory on the presented results, the explanation of the high predictability of voluntarism on high social trust is that the increased face-to-face relation that volunteering individuals in associations experience positively influence their level of social trust. The fact that they often meet other local citizens in these associations leads to an extensive reliance on others with regards to compliance with the norm of reciprocity, that is, contributing to the community. Newcomers in the community are taught the prevailing norms which helps to decrease transaction costs in cooperations within the community or association - there is no need for formal contracts every time a deal is made because both parties trust the other to comply with the terms of the deal. The deals that are agreed upon, directly or indirectly, are mostly kept because all parties have greater advantage by doing so, and the consequence of not keeping one's part of the deal is a social sanction which is unpleasant for an individual who wishes to become part of a community, for example a voluntary association. The specific trust that is built between voluntary workers affects each of the workers' trust in strangers, their social trust, which then arguably is one of the main reasons why the citizens of rural peripheral RSM today holds an extremely high level of social trust compared to the rest of Denmark and urban areas too.

Even though the reverse causal relationship has not been surveyed in this analysis, it can still be discussed here, although only in theory. Since the results from the analysis confirms the assumption that voluntary work to a great extent can explain high levels of social trust, it gives food for thought that Eric Uslaner in his analysis finds that life events similar to voluntarism apparently is of no greater importance to the level of social trust. The results from our analysis thus leads to speculations on which way the causality runs 
and this just confirms that we are far from reaching an agreement on the direction of the causality within the social trust literature. Furthermore, our analysis cannot be used to reject Uslaner's theory that social trust levels are influenced mainly by a child's upbringing. It is living proof that there is still a need for more in-depth causal analyses in order to determine who is right.

\section{Conclusion}

\section{BIBLIOGRAPHY}

AALBORG MUNICIPALITY (2017), Frivilligpris (“The Volunteer Award"), http://www.aalborg.dk/ oplevelser/frivillig/socialt-arbejde/frivilligpris.

BJØRNSKOV C. (2009), "Economic growth", in SVENDSEN G.T., SVENDSEN G.L.H. , Handbook of Social Capital: The Troika of Sociology, Political Science and Economics, Cheltenham, UK, Edward Elgar, pp. 337-353.

BOURDIEU P. (1986), "The forms of capital”, in RICHARDSON J.G., Handbook of Theory and Research for the Sociology of Education, New York, Greenwood Press, pp. 241-258. 
BUCHANAN J.M., TULLOCK G. (1962), The Calculus of Consent, Ann Arbor, University of Michigan Press.

CITIZEN PANEL SURVEY ON SOCIAL CAPITAL (2016), Social Capital Database, produced by Ringkøbing Skjern Municipality and Maria Arup Hovmand, Ringkøbing.

DOWNS A. (1957), An Economic Theory of Democracy, New York, Harper \& Row.

EPINION (2015), Borgerpanelets sammenscetning 2015 (“The composition of the Citizen Panel 2015"), Copenhagen.

EUROPEAN VALUES STUDY (2015), Home Page, http://www.europeanvaluesstudy.eu/.

FREITAG M. (2003), "Social Capital in (Dis)Similar Democracies: The Development of Generalized Trust in Japan and Switzerland”, Comparative Political Studies, 36, 8, pp. 936-966.

FUKUYAMA F. (2011), Origins of political order: from prehuman times to the French revolution (1 $1^{\text {st }}$ paperback ed.), New York, NY, Farrar, Straus and Giroux.

GOOGLE (2017), Google Maps , www.google.com/maps.

GREEN H. (2017), “Why Does Bernie Love Denmark?”, Huffington Post, Jan 05, 2017, http:// www.huffingtonpost.com/harlan-green/why-does-bernie-love-denm_b_8919626.html.

GUNDLACH E., SVENDSEN G.T. (2017), "How do high and low levels of social trust affect the longrun performance of poor economies?", Paper submitted to Public Choice.

HARDIN G. (1968), “Tragedy of the commons”, Science, 162, pp. 1234-1248.

HASKI-LEVENTHAL D. (2009), “Altruism and Volunteerism: The perceptions of altruism in four disciplines and their impact on the study of volunteerism", Journal for the Theory of Social Behaviour, 3, Blackwell Publishing Ltd., UK.

HILLERØD MUNICIPALITY (2017), FrivilligSocialprisen 2017: “The Volunteer Social Award 2017”, https://www.hillerod.dk/borger/kultur-idraet-og-oplevelser/frivillig-socialt-arbejde/ frivilligsocialprisen/.

JENSEN S., SVENDSEN G.T. (2016), "Safety and the choice of tourist destination: The case of Denmark", Business and Management Horizons, 4, 1, pp. 1-9.

KELMAN S. (1987), "Public Choice and Public Spirit”, Public Interest, 87, pp. 80-94.

MORLINO L. (1995), "Italy’s Civic Divide”, Journal of Democracy, 6, 1, pp. 173-177.

MUELLER D.C. (2003), Public Choice III, Cambridge, Cambridge University Press.

NORTH D.C. (1990), Institutions, Institutional Change and Economic Performance, Cambridge, Cambridge University Press.

OLSON M. (1965), The Logic of Collective Action, Cambridge, Cambridge University Press.

OSTROM E. (1990), Governing the Commons: the Evolution of Institutions for Collective Action, The Political Economy of Institutions and Decisions, Cambridge, Cambridge University Press.

OSTROM E. (1998), “A Behavioral Approach to the Rational Choice Theory of Collective Action: Presidential Address", The American Political Science Review, 1, pp. 1-22.

OSTROM E., AHN T.K. (2009), “The meaning of social capital and its link to collective action”, in SVENDSEN G.T., SVENDSEN G.L.H., Handbook of Social Capital - the Troika of Sociology, Political Science and Economics, $1^{\text {st }}$ ed., Cheltenham, UK, Edward Elgar Publishing Limited, pp. 17-35.

PORTES A., LANDOLT P. (1996), The Downside of Social Capital. The American Prospect, 18, May-June. 
POULSEN A. (2009), “Cooperation: evidence from experiments”, in SVENDSEN G.T., SVENDSEN G.L.H. (eds.), Handbook of Social Capital: The Troika of Sociology, Political Science and Economics, Cheltenham, UK, Northampton, MA, USA, Edward Elgar, pp. 36-56.

POULSEN A., SVENDSEN G.T. (2005), “Social capital and endogenous preferences', Public Choice, 123, pp. 171-196.

PUTNAM R.D. (2000), Bowling Alone - the Collapse and Revival of American Community, $1^{\text {st }}$ ed., New York, NY, Simon \& Schuster Paperbacks.

PUTNAM R.D. (1993), Making Democracy Work, $1^{\text {st }}$ ed., Princeton, NJ, Princeton University Press. RINGKøBING SKJERN MUNICIPALITY (2010), Frivilligprisen - pjece ("The Volunteer Award booklet"), Ringkøbing, Ringkøbing Skjern Municipality.

RINGKØBING SKJERN MUNICIPALITY (2017a), “Ringkøbing Skjern Municipality’s webpage”, www.rksk.dk.

RINGKØBING SKJERN MUNICIPALITY (2017b), Foreningsportal ("Portal of associations"), https:// www.conventus.dk/rksk/organisationer/start.php.

SKAT (2017), Foreninger (“Associations”), http://www.skat.dk/skat.aspx?oid=2234905.

SKOV O.R. (2015), "VIDEO Bernie Sanders til DR: Jeg flytter til Danmark, hvis jeg ikke bliver præsident”, DR Nyheder, Home Page https://www.dr.dk/nyheder/udland/video-bernie-sanderstil-dr-jeg-flytter-til-danmark-hvis-jeg-ikke-bliver-praesident.

SMITH A. (1766 [1997]), "Lecture on the influence of commerce on manners", in KLEIN D.B., Reputation: Studies in the Voluntary Elicitation of good Conduct, University of Michigan Press, Ann Arbor, pp. 17-20.

SøNDERSKOV K. (2015), Stata: A practical introduction, Copenhagen, Hans Reitzel Publishers. SVENDSEN G.L.H., SVENDSEN G.T. (2001), “Alleviating poverty: entrepreneurship and social capital in rural Denmark 1800-1900”, Belgeo, 1, 3, pp. 231-246.

SVENDSEN G.L.H., SVENDSEN G.T. (2015), "The Puzzle of the Scandinavian Welfare State and Social Trust", Issues in Social Science, 3, 2, pp. 90-99.

SVENDSEN G.L.H., SVENDSEN G.T. (2016a), Trust, Social Capital and the Scandinavian Welfare State: Explaining the Flight of the Bumblebee, Edward Elgar Publishing, Cheltenham, UK.

SVENDSEN G.L.H., SVENDSEN G.T. (2016b), "Homo Voluntarius and the Rural Idyll: Voluntary Work, Trust and Solidarity in Rural and Urban Areas", Journal of Rural and Community Development, 11, 1, pp. 55-72.

TIEBOUT C.M. (1956), "A Pure Theory of Local Expenditures”, Journal of Political Economics, 64, October 1956, pp. 416-424.

USLANER E.M. (2002), The Moral Foundations of Trust, New York, Cambridge University Press.

VAN INGEN E., BEKKERS R. (2015), “Generalized Trust Through Civic Engagement? Evidence from Five National Panel Studies”, Political Psychology, 36, 3, pp. 277-294.

WORLD VALUES SURVEY (2017), World Values Survey (1999-2004), World Values Survey Association. VOLUNTARISM AND DEDICATED SOUL ACADEMY (2016), Homepage, www.fi-akademiet.dk. VOLUNTEER COUNCIL (2011), Vedtcegter for Ringkøbing-Skjern Kommunes Frivilligråd ("Bylaws of Ringkøbing Skjern Municipality's Volunteer Council"), Denmark. 


\section{ABSTRACTS}

The Nordic countries hold the highest social trust scores in the world with averages up to $76 \%$. There are, however, regional differences. When measuring the level of social trust in a rural area such as Ringkøbing-Skjern Municipality (RSM), located in peripheral Denmark, the result is an astonishing score of $91 \%$. How can we explain why the RSM achieves such a high social trust score? One first answer could be based on Robert Putnam's theory on voluntary organizations. In fact, logistic regressions with predicted probabilities show that voluntary work has a strong positive effect on a citizen's social trust. This result is useful for geography as it shows that peripheral rural areas may perform extremely well in terms of social trust which again could be used by them as a new and overlooked brand for attracting newcomers.

Les pays nordiques présentent les taux les plus élevés au monde en matière de confiance sociale, avec des moyennes qui atteignent $76 \%$. Toutefois ces taux varient selon les régions. Si l'on mesure le niveau de confiance sociale dans une zone telle que la Municipalité de RingkøbingSkjern située en périphérie du Danemark, on obtient même le score impressionnant de $91 \%$. Comment expliquer une telle performance? Une première réponse pourrait être liée à la théorie de Robert Putnam relative aux organisations volontaires. En effet, les régressions logistiques qui permettent de réaliser des probabilités prédites montrent que le travail volontaire a un effet positif considérable sur la confiance sociale des citoyens. Un tel résultat pourrait être exploité par les géographes dans la mesure où il montre que les zones rurales situées en périphérie peuvent réaliser d'excellentes performances en termes de confiance sociale qui deviendraient leur nouvelle image de marque afin d'attirer de nouveaux arrivants.

\section{INDEX}

Keywords: rural area, newcomers, social trust, voluntary organizations, Denmark

Mots-clés: zones rurales, nouveaux arrivants, confiance sociale, organisations volontaires, Danemark

\section{AUTHORS}

\section{MARIA ARUP HOVMAND}

Graduated from Department of Political Science, Aarhus University, Denmark, maria@arup.dk GERT TINGGAARD SVENDSEN

Professor, PhD, Department of Political Science, Aarhus University, Denmark, gts@ps.au.dk 